University of Nebraska - Lincoln

DigitalCommons@University of Nebraska - Lincoln

1976

\title{
Comparison of Some Parameters of Serum and Uterine Fluid of Pregnant, Viviparous Sharks (Carcharhinus Leucas) and Serum of Their Near-Term Young
}

Thomas B. Thorson

University of Nebraska-Lincoln

Jeffrey W. Gerst

North Dakota State University

Follow this and additional works at: https://digitalcommons.unl.edu/ichthynicar

Part of the Aquaculture and Fisheries Commons

Thorson, Thomas B. and Gerst, Jeffrey W., "Comparison of Some Parameters of Serum and Uterine Fluid of Pregnant, Viviparous Sharks (Carcharhinus Leucas) and Serum of Their Near-Term Young" (1976). Investigations of the Ichthyofauna of Nicaraguan Lakes. 46.

https://digitalcommons.unl.edu/ichthynicar/46

This Article is brought to you for free and open access by the Papers in the Biological Sciences at DigitalCommons@University of Nebraska - Lincoln. It has been accepted for inclusion in Investigations of the Ichthyofauna of Nicaraguan Lakes by an authorized administrator of DigitalCommons@University of Nebraska Lincoln. 
Comp. Biochem. Physiol., 1972, Vol. 42A, pp. 33 to t0. Pergamon Press. Printed in Great Britain

\title{
COMPARISON OF SOME PARAMETERS OF SERUM AND UTERINE FLUID OF PREGNANT, VIVIPAROUS SHARKS (CARCHARHINUS LEUCAS) AND SERUM OF THEIR NEAR-TERM YOUNG
}

\author{
THOMAS B. THORSON and JEFFERY W. GERST
}

Department of Zoology, University of Nebraska, Lincoln, Nebraska 68508

\begin{abstract}
In eight females, serum urea concentrations of 134-336 mM/1. were interpreted as indications of previous environmental salinities.

2. Fetal serum solute concentrations usually resembled those of the mother, but in two cases where fetal urea was higher, it was interpreted as a lag in urea reduction following movement from salt to fresh water.

3. Uterine fluid was similar to maternal serum in all parameters except for its very low protein content.

4. No flushing of the uteri with environmental water occurs.

5. Independent osmoregulation apparently does not occur before birth, although required mechanisms may be present.

6. The full range of urea tolerance is present before birth.
\end{abstract}

\section{INTRODUCTION}

Most oviparous elasmobranchs enclose their eggs in a tough, keratinized egg case. The egg itself contains a high level of urea before becoming enclosed and the yolk sac prevents loss of urea to the fluid surrounding it. Later in development, four openings in the egg case, originally closed with solidified albumin, become unplugged and sea water enters the egg case and bathes the embryo. The embryo now functions in an environment, inside the egg case, essentially like that it will experience as an adult, but by this time, as demonstrated in Raja binoculata, its own urea production and retention mechanisms have become operative (Read, $1968 \mathrm{a} \mathrm{b}$ ), and it is able to regulate its osmotic components long before it emerges.

In the development of ovoviviparous elasmobranchs such as Squalus acanthias, the eggs and embryos are retained throughout development within the protection of the uterus. In the early stages, the egg capsule fluid and uterine fluid are quite similar to the maternal serum in regard to both urea content and inorganic ions. There is therefore little demand placed on the fetal osmoregulating system until later in development, when the adult female periodically flushes the uterus with sea water. The fetal environment then becomes essentially sea water and the fetus acquires its adult osmotic problems. In the ovoviviparous $S$. acanthias ( $=$ suckleyi), as in $R$. binoculata, the occurrence of ornithine carbamoyltransferase and arginase suggests the presence of a functional ornithine-urea cycle early in development (Read, 1968a). The ability to retain trimethylamine oxide also appears early in development of this species (Goldstein et al., 1967.) 
In viviparous forms, development also takes place entirely within the uterus. The embryo at first floats free and is nourished from the yolk of the egg. Later it either remains unattached, as in certain rays, and is nourished from uterine fluid content or histotroph secreted by the uterine walls; or, as in the smooth dogfish, Mustelus canis, it establishes a placental attachment of the yolk sac to the uterine wall. In any case, the egg capsule fluid before attachment, and the uterine fluid after attachment, are very similar in urea and chloride content, to that of maternal blood (Price \& Daiber, 1967). Flushing of the uterus apparently does not occur in $M$. canis and the urea-rich uterine environment is maintained throughout fetal development. In viviparous elasmobranchs, then, the rigors of the adult environment are not experienced until birth, and throughout intrauterine life, the demands on the fetal osmoregulatory mechanisms are negligible.

Although ornithine-urea cycle enzymes and urea retention may appear early in viviparous forms, as has been shown for oviparous and ovoviviparous types, this is not known, nor is the time of acquiring the ability to regulate osmotically, independently of the mother. Indeed, very little is known about the osmotic components of the fetal blood of viviparous species in relation to their fetal environment and the adult female's blood. Price \& Daiber (1967) analyzed embryonic blood for chloride, urea and depression of the freezing point in a single specimen of $M$. canis and two speciments of Myliobatis freminvillei, both viviparous species. They found that concentrations of chloride and urea were quite similar in both species to those of the uterine fluid and maternal blood, and the FPD of the three fluids were virtually identical. The species used by Price $\&$ Daiber are somewhat euryhaline, but are not long-term residents of fresh water and probably cannot tolerate fresh water for extended periods of time. In both cases, the experimental animals were taken from slightly diluted sea water (FPD $1.46^{\circ} \mathrm{C}$ for $M$. canis, and $1.62^{\circ} \mathrm{C}$ for $M$. freminvillei).

For investigation of the relation of fetal blood to the maternal fluids it would be of advantage to use a species that occurs in diverse environmental salinities and can tolerate the full range from fresh water to full strength sea water. The prime example of such an elasmobranch is the bull shark, Carcharhinus leucas, which occurs regularly in sea water along the coasts of both hemispheres as well as far up rivers and in some lakes. That they stay in fresh water for extended periods of time has been demonstrated conclusively by a tagging program in the Lake Nicaragua-Rio San Juan System (Thorson, unpublished data). However, although this shark is fully euryhaline, it apparently comes to brackish water around river mouths to drop its young (Springer, 1963). We have been able to procure pregnant females for our study at the mouth of the Rio Colorado, Costa Rica, the major outlet of the Rio San Juan, which drains Lake Nicaragua.

\section{MATERIALS AND METHODS}

Eight pregnant female Carcharhinus leucas containing near-term young were taken during the months of June, July and August of 1967, 1968 and 1970. They were caught by local fishermen on hand lines at the mouth of the Rio Colorado at Barra del Colorado, Costa Rica, and at a smaller outlet called Samay Lagoon, about $5 \mathrm{~km}$ south of Barra del Colorado. There was no control of the time or place of fishing, but all of the females were taken near 
the river mouth, inside if weather was bad and outside if it was calm. Inside the mouth the water was fresh at all depths at all times when we were present. Outside, it was always fresh at the surface, but at times there might be a layer of brackish water under the fresh water below 10 or $15 \mathrm{ft}$. Although the chances are strong that the sharks were all caught in fresh water, the immediate history of their movements in fresh and/or saline water was unknown.

Maternal blood was taken by cardiac puncture; that of the pups either by cardiac puncture or from a caudal vessel. Uterine fluid was drawn from the copious supply present in the uteri. Blood was allowed to clot and the serum was removed following centrifugation. Samples were frozen and taken to our laboratory in Lincoln for analysis.

Sodium, potassium and calcium were determined by flame photometry; magnesium by the titan yellow method of Heagy (1948); chloride by mercuric nitrate titration (Schales \& Schales, 1941); inorganic phosphorus by the method of Fiske \& Subbarow (1925); total protein by the biuret method (Weichselbaum, 1946); ammonia by Conway \& O'Malley's (1942) microdiffusion method; and urea by the procedure of Conway \& O'Malley (1942) or by the carbamido diacetyl reaction (Fearon, 1939). The urea methods were checked with each other, as well as with the Nessler reaction. As an approximation of the total osmotic concentration of each fluid, an "osmolar index" was calculated, consisting of the total of sodium, chloride and urea. All parameters are expressed in $\mathrm{mM} / 1$, except total protein which is recorded in $\mathrm{g} \%$.

\section{DISCUSSION OF RESULTS}

Sizes and weights of females and pups and numbers of pups per litter are shown in Table 1. On the basis of size, all of the pups can be judged to be near

Table 1-Length, Weight and hematocrit data ON FEMales and their Unborn Pups

\begin{tabular}{|c|c|c|c|c|c|c|c|c|}
\hline $\begin{array}{c}\text { Specimen } \\
\text { No }\end{array}$ & $\begin{array}{l}\text { Adult } \\
\text { length } \\
(\mathrm{cm})\end{array}$ & $\begin{array}{c}\text { Adult } \\
\text { weight } \\
\text { (kg) }\end{array}$ & $\begin{array}{l}\text { No. of } \\
\text { pups }\end{array}$ & $\begin{array}{l}\text { Average } \\
\text { fetal } \\
\text { length } \\
(\mathrm{cm})\end{array}$ & $\begin{array}{c}\text { Average } \\
\text { fetal } \\
\text { weight } \\
(\mathrm{kg})\end{array}$ & $\begin{array}{c}\text { Adult } \\
\text { hematocrit }\end{array}$ & $\begin{array}{c}\text { Average } \\
\text { fetal } \\
\text { hematocrit }\end{array}$ & S.E. \\
\hline 1 & 181 & 64 & 5 & 58 & $1 \cdot 44$ & $23 \cdot 3$ & 23 & \pm 0.60 \\
\hline 2 & 227 & 128 & 7 & 70 & $2 \cdot 74$ & $12 \cdot 3$ & 21 & \pm 0.78 \\
\hline 3 & 207 & 99 & 5 & 63 & - & $21 \cdot 7$ & 27 & \pm 0.97 \\
\hline 4 & 228 & - & 6 & $65 \cdot 1$ & $2 \cdot 08$ & - & - & - \\
\hline 5 & - & - & 3 & 65 & $2 \cdot 33$ & $25 \cdot 7$ & 23 & $\pm 1 \cdot 15$ \\
\hline 6 & 210 & 84 & 5 & 57 & 1.41 & $24 \cdot 0$ & - & - \\
\hline 7 & 201 & - & 4 & $67 \cdot 3$ & - & $13 \cdot 0$ & $23^{*}$ & - \\
\hline 8 & 202 & 75 & 3 & $62 \cdot 3$ & $2 \cdot 04$ & $28 \cdot 0$ & - & - \\
\hline
\end{tabular}

* Average of two specimens.

term. When placed in fresh water, ex utero pups of these sizes are extremely active, and neonatal sharks of this full size range are regularly taken on baited hooks or in seines.

The data for the eight females and their offspring are tabulated in Table 2. They are listed in the order of their urea content, which ranged, in the females, from 134 to $336 \mathrm{mM} / \mathrm{l}$. This represents very nearly the full range of urea variation 
from the strictly fresh-water level to the marine level (Smith, 1936; Urist, 1962; Thorson, 1967). Adult sharks of both sexes, but excluding pregnant females,

TABle 2-DATA ON Fluid PARAMETERS OF FEMALES AND THEIR UNBORN PUPS*

\begin{tabular}{|c|c|c|c|c|c|}
\hline \multirow[b]{2}{*}{ Parameter } & \multirow{2}{*}{$\begin{array}{l}\text { Adult } \\
\text { serum }\end{array}$} & \multirow{2}{*}{$\begin{array}{l}\text { Uterine } \\
\text { fluid }\end{array}$} & \multicolumn{3}{|c|}{ Fetal serum } \\
\hline & & & Average & S.E. & Range \\
\hline \multicolumn{6}{|c|}{ Specimen No. 1 (5 pups) } \\
\hline $\mathrm{Na}$ & 270 & 267 & 261 & \pm 9.65 & $246-299$ \\
\hline $\mathbf{K}$ & $6 \cdot 8$ & $5 \cdot 2$ & $7 \cdot 4$ & \pm 0.45 & $6 \cdot 2-8 \cdot 8$ \\
\hline $\mathrm{Cl}$ & 220 & 237 & 221 & $\pm 5 \cdot 03$ & 209-239 \\
\hline $\mathrm{NH}_{3}$ & $1 \cdot 2$ & $2 \cdot 0$ & 0.8 & \pm 0.05 & $0 \cdot 7-1 \cdot 0$ \\
\hline Urea & 134 & 143 & 149 & $\pm 7 \cdot 73$ & $132-172$ \\
\hline Osmolar index $\dagger$ & 624 & 647 & 631 & \pm 16.68 & $593-693$ \\
\hline \multicolumn{6}{|c|}{ Specimen No. 2 (7 pups) } \\
\hline $\mathrm{Na}$ & 286 & 230 & 254 & $\pm 2 \cdot 49$ & $244-260$ \\
\hline $\mathbf{K}$ & $10 \cdot 0$ & $6 \cdot 4$ & $5 \cdot 8$ & $\pm 0 \cdot 13$ & $5 \cdot 4-6 \cdot 2$ \\
\hline $\mathrm{Cl}$ & 262 & 205 & 235 & $\pm 2 \cdot 22$ & $226-244$ \\
\hline $\mathrm{NH}_{3}$ & $2 \cdot 6$ & $1 \cdot 5$ & $0 \cdot 7$ & \pm 0.08 & $0 \cdot 3-1 \cdot 0$ \\
\hline Urea & 146 & 154 & 159 & \pm 1.90 & $153-166$ \\
\hline Osmolar index $\uparrow$ & 694 & 589 & 648 & \pm 3.74 & $632-658$ \\
\hline \multicolumn{6}{|c|}{ Specimen No. 3 (5 pups) } \\
\hline $\mathrm{Na}$ & 338 & 250 & 288 & $\pm 10 \cdot 40$ & $272-328$ \\
\hline $\mathbf{K}$ & $7 \cdot 8$ & $6 \cdot 4$ & 6.7 & \pm 0.38 & $5 \cdot 2-7 \cdot 4$ \\
\hline $\mathrm{Cl}$ & 220 & 239 & 226 & $\pm 8 \cdot 67$ & $202-244$ \\
\hline $\mathrm{NH}_{3}$ & $1 \cdot 7$ & $1 \cdot 7$ & $0 \cdot 8$ & \pm 0.06 & $0 \cdot 7-1 \cdot 0$ \\
\hline Urea & 164 & 161 & 177 & $\pm 9 \cdot 01$ & $156-204$ \\
\hline Osmolar index ${ }^{\dagger}$ & 722 & 650 & 691 & $\pm 15 \cdot 74$ & $638-728$ \\
\hline \multicolumn{6}{|c|}{ Specimen No. 4 (6 pups) } \\
\hline $\mathrm{Na}$ & 239 & 226 & 258 & $\pm 5 \cdot 75$ & $235-275$ \\
\hline $\mathbf{K}$ & $5 \cdot 8$ & $4 \cdot 4$ & $7 \cdot 4$ & \pm 0.79 & $6 \cdot 3-11 \cdot 3$ \\
\hline $\mathrm{Cl}$ & 249 & 198 & 217 & $\pm 7 \cdot 89$ & $186-240$ \\
\hline $\mathrm{NH}_{3}$ & $7 \cdot 2$ & $1 \cdot 3$ & $1 \cdot 1$ & \pm 0.05 & $0 \cdot 9-1 \cdot 3$ \\
\hline Urea & 176 & 207 & 212 & \pm 9.02 & $195-254$ \\
\hline Osmolar index $\dagger$ & 664 & 631 & 686 & $\pm 10 \cdot 15$ & $658-715$ \\
\hline \multicolumn{6}{|c|}{ Specimen No. 5 ( 3 pups) } \\
\hline $\mathrm{Na}$ & 229 & 252 & 243 & \pm 3.06 & $237-247$ \\
\hline $\mathbf{K}$ & $3 \cdot 9$ & $4 \cdot 5$ & $5 \cdot 0$ & $\pm 0 \cdot 17$ & $4 \cdot 8-5 \cdot 3$ \\
\hline $\mathrm{Cl}$ & 202 & 225 & 266 & $\pm 32 \cdot 72$ & $227-331$ \\
\hline $\mathrm{NH}_{3}$ & $1 \cdot 3$ & $2 \cdot 1$ & $1 \cdot 3$ & $\pm 0 \cdot 20$ & $1 \cdot 0-1 \cdot 7$ \\
\hline Urea & 196 & 204 & 203 & \pm 3.84 & $195-207$ \\
\hline Osmolar index $\dagger^{\dagger}$ & 627 & 681 & 712 & $\pm 31 \cdot 90$ & $668-744$ \\
\hline \multicolumn{6}{|c|}{ Specimen No. 6 ( 5 pups) } \\
\hline $\mathrm{Na}$ & 252 & 244 & 246 & \pm 0.98 & $242-248$ \\
\hline $\mathrm{K}$ & 6.0 & $3 \cdot 8$ & $6 \cdot 2$ & \pm 0.32 & $5 \cdot 0-6 \cdot 8$ \\
\hline
\end{tabular}


TABLE 2-(cont.)

\begin{tabular}{|c|c|c|c|c|c|}
\hline \multirow[b]{2}{*}{ Parameter } & \multirow{2}{*}{$\begin{array}{l}\text { Adult } \\
\text { serum }\end{array}$} & \multirow{2}{*}{$\begin{array}{l}\text { Uterine } \\
\text { fluid }\end{array}$} & \multicolumn{3}{|c|}{ Fetal serum } \\
\hline & & & Average & S.E. & Range \\
\hline $\mathrm{Ca}$ & $5 \cdot 3$ & $4 \cdot 0$ & $4 \cdot 0$ & $\pm 0 \cdot 20$ & $3 \cdot 2-4 \cdot 3$ \\
\hline $\mathrm{Mg}$ & $3 \cdot 4$ & $2 \cdot 5$ & $2 \cdot 1$ & \pm 0.07 & $2 \cdot 0-2 \cdot 4$ \\
\hline $\mathrm{Cl}$ & 245 & 237 & 239 & $\pm 1 \cdot 66$ & $233-243$ \\
\hline$P_{i}$ & $2 \cdot 1$ & - & $3 \cdot 5$ & $\pm 0 \cdot 22$ & $3 \cdot 0-4 \cdot 2$ \\
\hline Total protein $(g \%)$ & $3 \cdot 3$ & Trace & $2 \cdot 0$ & $\pm 0 \cdot 10$ & $1 \cdot 0-2 \cdot 3$ \\
\hline Urea & 214 & 207 & 215 & $\pm 2 \cdot 35$ & $207-218$ \\
\hline Osmolar index $\uparrow$ & 711 & 688 & 699 & $\pm 1 \cdot 16$ & $695-702$ \\
\hline \multicolumn{6}{|c|}{ Specimen No. 7 (4 pumps) } \\
\hline $\mathrm{Na}$ & 225 & - & 258 & $\pm 7 \cdot 29$ & $237-270$ \\
\hline $\mathrm{K}$ & $4 \cdot 9$ & - & $6 \cdot 7$ & $\pm 0 \cdot 25$ & $5 \cdot 9-7 \cdot 0$ \\
\hline $\mathrm{Ca}$ & $3 \cdot 7$ & - & $4 \cdot 4$ & $\pm 0 \cdot 32$ & $3 \cdot 7-4 \cdot 8$ \\
\hline $\mathrm{Mg}$ & $1 \cdot 7$ & - & $1 \cdot 1$ & $\pm 0 \cdot 06$ & $1 \cdot 1-1 \cdot 3$ \\
\hline $\mathrm{Cl}$ & 256 & - & 217 & $\pm 2 \cdot 92$ & $209-223$ \\
\hline$P_{i}$ & - & - & $2 \cdot 9$ & \pm 0.48 & $1 \cdot 6-3 \cdot 9$ \\
\hline Total protein $(g \%)$ & $2 \cdot 4$ & - & $1 \cdot 9$ & \pm 0.13 & $1 \cdot 5-2 \cdot 1$ \\
\hline Urea & 309 & - & 429 & $\pm 9 \cdot 17$ & $410-453$ \\
\hline Osmolar index $\dagger$ & 790 & - & 904 & $\pm 5 \cdot 28$ & 889-913 \\
\hline \multicolumn{6}{|c|}{ Specimen No. 8 (3 pups) } \\
\hline $\mathrm{Na}$ & 249 & 250 & 257 & $\pm 1 \cdot 76$ & $254-260$ \\
\hline $\mathrm{K}$ & $5 \cdot 1$ & $5 \cdot 9$ & $5 \cdot 8$ & $\pm 0 \cdot 31$ & $5 \cdot 4-6 \cdot 4$ \\
\hline $\mathrm{Ca}$ & $5 \cdot 3$ & $4 \cdot 0$ & $4 \cdot 9$ & $\pm 0 \cdot 07$ & $4 \cdot 8-5 \cdot 0$ \\
\hline $\mathrm{Mg}$ & $2 \cdot 2$ & $2 \cdot 2$ & $2 \cdot 3$ & \pm 0.03 & $2 \cdot 3-2 \cdot 4$ \\
\hline $\mathrm{Cl}$ & 243 & 255 & 252 & $\pm 1 \cdot 33$ & $251-255$ \\
\hline$P_{i}$ & $3 \cdot 2$ & $2 \cdot 6$ & $3 \cdot 3$ & $\pm 0 \cdot 13$ & $3 \cdot 2-3 \cdot 6$ \\
\hline Total protein (g \%) & $4 \cdot 0$ & Trace & $1 \cdot 9$ & \pm 0.03 & $1 \cdot 8-1 \cdot 9$ \\
\hline Urea & 336 & 321 & 326 & $\pm 19 \cdot 00$ & $307-364$ \\
\hline Osmolar index $\dagger$ & 828 & 826 & 836 & $\pm 18 \cdot 68$ & $816-873$ \\
\hline
\end{tabular}

* All parameters expressed in $\mathrm{mM} / \mathrm{l}$. except total protein (g \%).

$\uparrow$ Total of sodium, chloride and urea.

taken at this same river mouth, also show urea levels characteristic of the full range of environmental salinities (Thorson, unpublished data). The urea level is interpreted as an indication of the immediate history of the sharks' movements. The pregnant females are found in both fresh and salt water and direct observations indicated that they move freely between the two media. Since their suggested environmental histories differ sharply, they must be treated separately.

In the two extreme cases, No. 1 which apparently had been in fresh water, and No. 8 in salt water, the serum parameters of the pups were virtually identical with those of the mothers. This was true of most of the intermediate specimens as well.

There was a considerable amount of variation among the pups of each litter and the ranges usually overlapped the maternal values. 
However, in No. 4 the average, as well as the range, of fetal urea is sufficiently higher than the maternal urea to suggest an effect that keeps them apart. In No. 7 the difference was even more pronounced. The urea in this female was $309 \mathrm{mM} / 1$. while the average fetal urea was 429 , with a range of 410 to 453 . The total of sodium and chloride of mother and pups was virtually identical. Since most of the litters had urea similar in concentration to that of their mothers, it is suggested that, throughout the range of environmental salinity, the young assume the approximate urea concentration of the mother, shifting as the mother shifts with changes in external salinity. However, if the adult moves quickly from greater salinity to less, or vice versa, the change in the fetal urea level lags that of the mother, thus accounting for the disparity exhibited in Nos. 4 and 7.

Although in certain individual instances there are some apparent differences in the other parameters, there is no pattern evident that appears to be related to difference in external salinity except the proposed case of urea. In general, the osmotic index also shows a gradual increase as the urea concentration increases

The total protein of twelve pups averaged $1.9 \mathrm{~g} \%$ (range, $1 \cdot 0-2 \cdot 3$ ), whereas three adults averaged 3.2 , with a range of $2 \cdot 4-4.0 \mathrm{~g} \%$. The lower protein content of fetal serum agrees with the observation of Cowan (1972).

Small concentrations of ammonia are found in all three fluids, but it appears to be lowest in the fetal serum. The average of twenty-six pups was $0.9 \mathrm{mM} / 1$, while five samples of uterine fluid had 1.9 and five adult females had 2.8. The latter figure includes one unexplainably high figure of $7 \cdot 2$. Exclusive of that figure, the concentration of ammonia for female serum would be $1 \cdot 7$, about the same as that of the uterine fluid.

In Table 1 it will be noted that five fetal litters had hematocrit values from 21 to 27 and that in three cases, these were fairly close to those of the adults. However, in Nos. 2 and 7, the adult hematocrit was very low, 12.3 and 13, respectively, but the fetal hematocrit remained within expected limits. We have no explanation for the low values in the two adults. No excessive bleeding was noted at the time of capture, nor is it indicated by the concentrations of serum constituents in Table 2. These two females were bearing the two largest litters of pups (average length, 70 and $67.3 \mathrm{~cm}$ ) and were therefore probably closest to parturition. The lips of the cloaca become swollen and red shortly before parturition, but we have never observed bleeding, nor blood in the uterine fluid.

As reported by Price \& Daiber (1967) for $M$. canis, the uterine fluid strongly resembles the maternal serum in most parameters. However, only a trace of protein was found in the two uterine fluid samples analyzed for protein, whereas the adult serum averaged $3.2 \mathrm{~g} \%$ in three females. In its lack of protein, the uterine fluid resembles perivisceral and pericardial fluids, which also are virtually free of protein in elasmobranchs (Bernard et al., 1966; Thorson, 1967).

Since these females are very near to parturition and the uterine fluid is still of a composition similar to that of the maternal serum, it is obvious that no flushing of the uterus with environmental water occurs. 
Although in individual cases, small differences appear between uterine fluid and maternal serum, there is no discernible pattern to indicate whether shifts in the concentration of uterine fluid components lead or lag those of the fetus; nor is there any evidence as to the relative roles played in determining the composition of uterine fluid by hydrostatic filtration, diffusion and secretion by the uterine wall or possible exchanges with the fetuses. The fetus lies directly in the uterine fluid, which certainly bathes the gills and must receive excretory wastes produced by the pups. The fact that there is no appreciable accumulation of any constituent studied in fetus or uterine fluid indicates that maternal circulation carries away the excess; and since fetal levels of urea and inorganic ions are not below those of the mother, the pups obviously do not regulate below maternal levels.

Although we have no evidence for the time of onset of urea production and osmotic regulation, it is clear that the full adult range of urea tolerance is present before birth.

Although they probably are, as a rule, born in brackish water, as claimed (Springer, 1963), the young would likely be capable of survival born in any freshwater or marine salinity.

Acknowledgements-Some of the laboratory work was done by C. Michael Cowan. This research was supported by N.I.H. Grant HE-09075 and by the University Research Council of the University of Nebraska.

\section{REFERENCES}

Bernard G. R., WynN R. A. \& WYNN G. G. (1966) Chemical anatomy of the pericardial and perivesical fluids of the stingray, Dasyatis americana. Biol. Bull. mar. biol. Lab., Woods Hole 130, 18-27.

Conway E. J. \& O'Malley E. (1942) Microdiffusion methods. Ammonia and urea using buffered absorbents. Biochem. F. 36, 655-661.

Cowan C. M. (1972) Serum protein variation in the bull shark, Carcharhinus leucas (Müller and Henle), 1841. Int. $\mathcal{F}$. Biochem. (In press.)

Fkaron W. (1939) The carbamido diacetyl reaction: a test for citrulline. Biochem. F. 33, 902-907.

Fiske C. H. \& Subbarow Y. (1925) The colorimetric determination of phosphorus. $\mathcal{F}$. biol. Chem. 66, 375-400.

Goldstein L., Hartman S. C. \& Forster R. P. (1967) On the origin of trimethylamine oxide in the spiny dogfish, Squalus acanthias. Comp. Biochem. Physiol. 21, 719-722.

Heagy F. C. (1948) Determination of magnesium in body fluids by the use of Titan Yellow. Can. F. Res. 26E, 295.

Price K. S., JR. \& Daiber F. C. (1967) Osmotic environments during fetal development of dogfish, Mustelus canis (Mitchill) and Squalus acanthias Linnaeus, and some comparisons with skates and rays. Physiol. Zoöl. 40, 248-260.

Read L. J. (1968a) Ornithine-urea cycle enzymes in early embryos of the dogfish Squalus suckleyi and the skate Raja binoculata. Comp. Biochem. Physiol. 24, 669-674.

READ L. J. (1968b) Urea and trimethylamine oxide levels in elasmobranch embryos. Biol. Bull. mar. biol. Lab., Woods Hole 135, 537-547.

Schales O. \& Schales S. S. (1941) A simple and accurate method for the determination of chloride in biological fluids. $\mathcal{F}$. biol. Chem. 140, 879-884.

Smith H. W. (1936) The retention and physiological role of urea in the Elasmobranchii. Biol. Rev. 11, 49-82. 
SPRINGER S. (1963) Field observations on large sharks of the Florida-Caribbean region. In Sharks and Survivial (Edited by GilBeRT P. W.), pp. 95-113. D. C. Heath, Boston.

Thorson T. B. (1967) Osmoregulation in fresh-water elasmobranchs. In Sharks, Skates and Rays (Edited by Gilbert P. W., Mathewson R. F. \& Rall D. P.), pp. 265-270. Johns Hopkins Press, Baltimore.

URIST M. R. (1962) Calcium and other ions in blood and skeleton of Nicaraguan freshwater shark. Science, N.Y. 137, 984-986.

WeichSELBAUM T. E. (1946) An accurate and rapid method for the determination of proteins in small amounts of blood serum and plasma. Am. F. clin. Path. 7, 40-49.

Key Word Index-Bull sharks; body fluids; Carcharhinus leucas; Chondrichthyes; Elasmobranchii; fetal serum; pregnant sharks; Selachii; serum parameters; shark serum; urea; uterine fluid; viviparous sharks. 